\title{
When Writers Activate Readers How the autofictional blog transforms Arabic literature ${ }^{*}$
}

\author{
TERESA PePE (University of Oslo)
}

\begin{abstract}
The adoption of Internet technology in Egypt has led to the emergence a new literary genre, the 'autofictional blog'. This paper explores how this genre relates to the Arabic understanding of literature, using as examples a number of Egyptian autofictional blogs written between 2005 and 2011. The article shows that the autofictional blog transforms 'adab into an interactive game to be played among authors and readers, away from the gatekeepers of the literary institutions, such as literary critics and publishers. In this game the author adopts a hybrid genre and mixed styles of Arabic and challenges the readers to take an active role in discovering the identity hidden behind the screen and making their way into the text. The readers, in return, feel entitled to change and contribute to the text in a variety of ways.
\end{abstract}

Key words: autofictional blog; 'adab; modern Arabic literature; Egypt

The adoption of the Internet has favoured the proliferation of new forms of autobiographical writing and literary creativity all over the world. Blogs ${ }^{1}$ in particular are used by Internet users worldwide to record and share their writing.

The popularity of the blogging phenomenon and the original features of blog texts have also attracted the interest of international scholars. More specifically, a particular kind of blog defined as the "personal blog", which consists of "a blog written by an individual and focusing on his or her personal life" (WALKER 2005), has spurred a significant debate. Most academics agree that the personal blog should be considered a form of diary (LEJEUNE 2000, MCNEILL 2003), thus inserting it in the category of (auto-)biographical writing. It is true that the personal blog shares some features with the diary genre, in that its content is mainly autobiographical and it consists of dated entries, arranged chronologically (in reverse order). However, in addition to recording the user's life, personal blogs allow users to play with their identity, to reveal aspects of their personality while inventing new ones. In his article "The Labyrinth Unbound: The Weblog as Literature", Steve HIMMER points out that besides the record of bloggers' daily lives, personal blogs may include short

This article is a slightly reworked version of a public lecture given at the University of Oslo, Norway, on 13 June, 2014, as "Life-writing on the Net: Hybrid Genre and Blurred Identities. How Does the Autofictional Blog Transform Our Understanding of Literature?"

1 A weblog may be defined as a "frequently updated website consisting of dated entries arranged in reverse chronological order" (WALKER 2005). 
stories, film reviews, comments about music, book reviews, song videos, and calls for meetings, social events, and political demonstrations; therefore "the fictional is blended with the outside reality and the extra-literary world, the personal is strongly intermingled with the public, and the personal and the political are not discernible" (HIMMER 2004). Building on these remarks, Kathleen FITZPATRICK, in her article "The Pleasure of the Blog", argues that "reducing the personal blog to no more than online diaries or domestic ranting, we are effectively casting aside un-theorized an entire mode of blogging that has a significant literary potential" (2007: 173), and therefore personal blogs might fruitfully be approached as an "emergent literary form" (2007: 168). This ongoing debate shows that personal blogs call for further research, as they are symptomatic of how the Internet forces us to rethink across categories of genre and identity in order to reformulate our understanding of what literature is.

In this sense, Egyptian personal blogs provide an interesting case for analysis. Since $2005,^{2}$ when the Internet became more accessible in the Arab world, many young Egyptians have resorted to blogs to create a space for self-expression and literary experimentation. The availability of personal spaces for writing, unedited and relatively uncensored, ${ }^{3}$ has encouraged amateur as well as more skilled writers to try their hand at writing in this new and uncategorized genre.

In her book Gender, Nation and the Arabic Novel, Hoda EL-SADDA has argued that Internet technologies, inasmuch as they have empowered and inspired the new generation of youth to political dissent and organization, ${ }^{4}$ have also opened up new possibilities for literary voices to imagine new realities (2012: 214). In a previous article, "Arab Women Bloggers: The Emergence of Literary Counterpublics", she analyzes three book-blogs 5 and argues that "blogging has resulted in the creation of literary counterpublics, forums for alternative literary genres, languages and style that are adjacent or parallel to mainstream literary centers" (EL-SADDA 2010: 315). By studying the same book blogs as El-Sadda and comparing them to three Egyptian print novels, Marie Thérèse ABDEL-MESSIH (2009: 515)

2 In 2005, the Egyptian government improved Internet infrastructure and reduced the prices for Internet access. For a historical account of the Egyptian blogosphere, see RADSCH 2008 and NĀĞİ 2010.

3 Until 2011 very few incidents took place, which have given rise to worries concerning freedom of expression online, such as the arrest and sentencing of the blogger Karīm 'Āmir to four years in prison for insulting religion and the state in 2007. (See <http://www.hrw.org/news/2007/02/21/egypt-bloggers-imprisonment-sets-chilling-precedent>, last accessed 10/03/2014.) Worthy of attention is the fact that the Internet, together with mobile phone lines, was shut down on 28 January, the third day of the January 2011 uprisings. A recent report by Amnesty International (June 2014) warns that the government headed by 'Abd al-Fattāh al-Sīsī is planning to introduce a new system to carry out indiscriminate mass surveillance of social media in Egypt. See $<$ https://www.amnesty.org/ en/articles/ news/2014/06/egypt-s-attack-internet-privacy-tightens-noose-freedom-expression/>, last accessed 10 March, 2014.

4 On the role of Internet technologies in the Egyptian uprisings see FARIS 2013.

5 In 2008, three Egyptian blogs written by three women bloggers were published by Dār al-Šurūq, the biggest private Egyptian publishing house, and could be found on the best-seller lists of Cairo bookshops. In the following years, many more blogs have been turned into print. For more on Egyptian blog-books see PEPE 2011. 
argues that a new generation of writers, which has emerged from the world of blogging has begun to initiate a break with former narrative modes. Similarly, in his article "Hacking the Modern", Tarek EL-ARISS looks at the intersection between print and digital in the avantgarde novel 'An takün 'Abbās al-'Abd (2003; translated into English as Being Abbas el-Abd, 2006) by the Egyptian author 'Ahmad AL-'̄̄YDĪ, and points out that the new technologies are used as a fictional device to foster politically and aesthetically subversive transformations in Arabic literature (2010: 545).

These studies emphasize the importance of exploring the ruptures introduced into Arabic literature by the Internet technologies. However, the authors of these studies discuss the impact of the Internet medium on Arabic literature by looking mainly at literary print works. Therefore, they highlight the urgency of studying these transformations by exploring the intricate web of the blogosphere. In fact, only by looking at a large sample of online texts will we be able to understand the unique features that Arabic literature has developed on the web.

My research in the Egyptian blogosphere highlights that the experimentation with blogging, in particular with the subgenre of personal blogs, has led to the emergence of a new writing genre in Arabic literature that may be defined as the 'autofictional blog. ${ }^{6}$ The genre consists of an online literary autobiographical account that is characterized by a seamless mix of fiction and non-fiction. It is a hybrid genre that mixes autofictional narrative strategies with the aesthetic features provided by the Internet structure, such as the possibility of combining writing with links and audio and video elements and of updating and modifying the text at any time. In addition, the Internet structure promises a freedom of style and content allegedly not to be found elsewhere, since bloggers do not have to undergo the scrutiny of the gatekeepers of the literary field, such as editors, publishers, and critics.

In this paper, I will explore the literary quality of the autofictional blogs and how it transforms our understanding of literature.

Since 'literature' is in itself a very vague term whose meaning is constantly changing, I find it helpful to discuss this question in the framework of the concrete example provided by a number of Egyptian autofictional blogs published between 2005 and 2011, and relate these to the realm of modern Arabic literature.

In my analysis, I will proceed by first relating autofictional blogs to the Arabic notion of a modern 'adab. Then, drawing on theories of autofiction, digital literature, and Arabic print literature, I will explore the innovative features of these texts resulting from the adoption of the Internet technology. These are (1) interactivity, (2) the blurring of the author/main character, (3) the multimedia, open nature of the blog texts, and (4) their stylistic features. I argue that the combination of these elements transforms 'adab into an interactive game to be played among authors and readers, away from the gatekeepers of the literary institutions. By depicting modes of interaction between readers and writers in the Egyptian

6 I coined this term to describe some personal blogs dealing mainly with the authors' lives and presenting some elements of literariness. 'Autofiction' denotes a postmodern form of literary autobiography. It is usually used to describe a novel in which the author is also the narrator and main character in the story, as in autobiographies. For a more theoretical explanation of "autofiction" see JONES 2009. On the application of the term 'autofiction' to Egyptian blogs see PEPE 2012. 
blogosphere, I will show how the autofictional blog requires the readers to be active participants in the interpretation of the text by discovering the blurred identity of the author/main character; to find their way in the open, multimedia text; and to contribute actively to the plot and style of the narrative.

\section{The 'adab Dimension of Modern Arabic Literature}

A possible way of describing the Arabic traditional understanding of 'literature' is to go back to the rich meaning of 'adab, as the French scholar R. Jacquemond has done in his book Conscience of the Nation (2008 [2003]). 'Adab is the word used in Modern Standard Arabic for 'literature' nowadays, but the concept is much older. In classical times, 'adab meant, among other things, a corpus of beautiful, entertaining, and at the same time useful works written in a high variety of language. ${ }^{7}$ The term also implies a moral component, in the sense of '(mostly) secular norms of conduct', '(ethical) normativity'. Then, during the nahdah (the so-called Arabic 'renaissance'), a period of intellectual modernization and reforms that took place in the late 19th and early 20th, a transformation of the term 'adab took place in that it began to include literary genres such as the novel, short stories, and drama, and therefore notions of fictionality, originality, and creativity.

JACQUEMOND (2008) explains that the ancient meaning of the word 'adab informed the shaping of a 'modern' literary imaginary throughout the nahdah. The idea of 'adab as instruction through entertainment could be seen in the fact that the novelistic genre, for example, was admitted into the realm of 'adab by presenting itself as a moral or didactic type of writing that claimed to be as realistic as possible and thus removed from fiction; it was adopted by nationalistic modern writers to forge the idea of a nation and national identity, as is ably shown by Samah SELIM (2004) and Hoda EL-SADDA (2012), among others. Short stories and dramatic pieces were also used by Arab writers in order to illustrate social problems. Later, the idea of ' $a d a b$ as instruction through entertainment resulted in 'adab's taking the form of committed literature ('adab multazim). ${ }^{8}$

7 The origin of the word is probaby in the plural 'ā $\bar{a} \bar{a} b$ with metathesis from 'ad'a $\bar{a} b$, sing. $d a b$, which means "norms and customs, tradition", so the word 'adab coincided largely with the word sunna, which in Islamic times came to signify the tradition and customs of the Prophet. After the spread of Islam, as the sunna started to be used exclusively to indicate the norms of the Prophet, 'adab acquired a different meaning; it meant both moral education, the corpus of good norms, and the sum of all non-religious knowledge. Thus, the main purpose of 'adab was "to discipline the mind and to teach, educate". For a further discussion about the word 'adab see the etymological-conceptual study "Politeness, Höflichkeit, 'adab" by S. GUTH (2010).

8 Andreas PFLITSCH writes that since 1947, when Țāhā HuUSAYN adopted the expression littérature engagée (engaged literature) from Jean-Paul SARTRE and introduced it into the Arabic intellectual debate, the main issues of discussion have been the means of this commitment. In his words: "at issue was not whether literature should be committed to social and political causes but how it was to undertake this mission" (PFLITSCH 2010: 29). PFLITSCH argues that, generally, this has remained the case until the time of his own writing (2010). For a discussion of the notion of iltizäm (engagement) see KLEMM 2000. 
JACQUEMOND argues that this understanding of 'adab continues to define what legitimate literature is and what it is not, as good literature is supposed to be entertaining and useful at the same time (2008: 10).

Apart from that, the ancient idea that 'adab has to conform to linguistic norms was at the center of the nahdah's linguistic project to revive and simplify the Arabic language, and can still be seen today in the fact that good literature is supposed to be written in a high variety of language. As a result, works written in the vernacular have thus far been devalued as 'low' literature or folklore (JACQUEMOND 2008: 9).

However, one can think of numerous examples of Arab literary works that challenge this definition of 'adab. In fact, as Jacquemond points out, over the years, writers and critics have struggled over the definition of what literature is and what it does. He therefore concludes that the distribution of literary practices has resulted into "a generalized interaction and hybridization between elevated and popular forms, native, imported, modern and traditional forms, to the point that no fixed boundary exists between legitimate literature and various other forms of literary practice" (2008: 153).

Internet technology has provided Egyptian amateur and professional writers with additional means to challenge the traditional view of 'adab by enriching it with new meanings and functions.

Going back to the notion of 'adab illustrated above (useful, entertaining, and written in a high variety of language), it is possible to see that some aspects of tarbiya (education) and tasliya (entertaining) can be found to some extent in the autofictional blog.

Many bloggers write in pursuit of literary aspirations and share their writings because they might be edifying and useful for the community. The word used for 'blog', mudawwanah, is a passive participle (or nomen loci) from the verb dawwanah and thus means 'what is registered, rendered official by putting on paper' (or the place where this is done). ${ }^{9}$ In this sense the function of the blogger resembles the function of the 'adī $b$ (writer of ' $a d a b$ ), whose task is to record, to document history, besides producing a creative work (JACQUEMOND 2008: 4).

This writing is often informed by political aspirations (and is therefore considered useful for society). Many bloggers write about their life as a means of changing the society surrounding them. This is evidenced, for example, by the following words written by the blogger 'Abīr SULAYMĀN as an introduction to her blog Yawmiyyāt 'Ānis (Diary of a Spinster):

$$
\begin{aligned}
& \text { فقررت اتخاذ خطوة جريئة الى الأمام .... سأكتب يومياتى - كعانس من وجهة نظر المختمع .... و }
\end{aligned}
$$

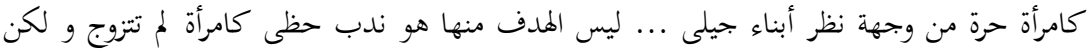

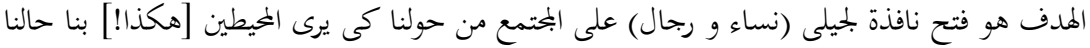

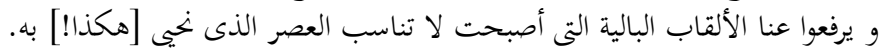

9 The term is obviously a calque (loan translation), coined after English blog, a truncation of (web) $\log$. Log is used here in the sense of logbook, originally a nautical term that by extension came to signify 'a book in which events are recorded; a journal, especially of travel' (Wiktionary, s.v. logbook). 
So, I decided to take a brave step forward ... I will write my diaries - as a spinster from the point of view of society ... and as a free woman from the point of view of my generation ... My goal is not to bemoan my (bad) luck as a woman who did not marry, but rather to open a window so that my generation (women and men) looks through to see the surrounding society, and so that those surrounding us can see our situation and can relieve us from the worn-out titles which do not suit the time we live in anymore (1 June 2008).

These words highlight that SULAYMĀN is willing to share her life because this might be useful for her peers. By writing about her life, she aims to change the society around her, showing that the prejudices against unmarried people in Egypt do not reflect reality.

As for their entertaining quality, autofictional blogs seem to be engaging and compelling to read, as evidenced by the large readership that many of these blogs have gathered both online and in print. Many bloggers, such as Muhammad Rabī', 'Aḥmad NĀĞİ, and 'Ahmmad al-Faharānī, have later turned to novel writing and are now at the forefront of the Egyptian literary avant-garde, receiving great acclaim among critics and readers.

However, bloggers dislike being called ' $u d a b \vec{a}^{\prime}$ because they do not see themselves in the tradition of those to whom this term has so far been applied. ${ }^{10}$ By using the blog, they hope to change the traditional notion of literature as 'adab; they are eager to produce something new. This point is made explicit in a passage entitled Mulāhazāt hawl al-'adab (Notes about Literature; 2 November 2005) published in the blog Wassi` hayālak - iš ka'annak tal'ab (Widen your imagination - Live as if you were playing), written by the Egyptian blogger and writer 'Aḥmad NĀĞĪ in November 2005:

$$
\text { ويشرخ له سلامه الروحي ويجرحه في مشاعل أديد هـذا!] من الأفيون... أدب لا يقدم الراحة للقارئ بل يقدم له القلق }
$$

We have to produce a new opium-free 'adab ... an 'adab that does not give rest to the reader but rather arouses anxiety, and that cracks the peace of his spirit and wounds his feelings.

As shown by the passage above, NĀĞİ and his peers want to transform this notion of 'adab and revolt because they think that its aesthetics and ideology resulted in a complete exclusion of the reader. The metaphor of the opium shows that they accuse their literary fathers of having (ab)used 'adab as a means of sedating the readers and making them accept a political, ideological project that was doomed to collapse (as shown six years later by the political uprisings that culminated in the fall of Mubarak's regime).

For bloggers, 'adab should instead make itself useful by delivering a highly irritating, discomforting, rebellious message that the readers have to interpret by themselves and can contribute to shaping.

This attention to the reader had already been advocated earlier in Arabic literature, by critics like the theoretician of 'national literature' ('adab qawmì) 'I $\bar{s} \bar{a}$ 'UBAYD, in the

10 This is evidenced by my interviews with the authors. For my research I interviewed 30 Egyptian bloggers in Cairo and Alexandria, in 2011 and 2012. 
muqaddima (introduction) to his collection of short stories, Ihsān Hānim (1964 [1921]). In his muqaddima, 'Ubayd rejected earlier traditionalism and neoclassicism as dated and elitist, as well as Manfalūtian 'romanticism' as too idealistic and 'passive'; he called instead for a non-elitist, functional style (GUTH 2013). Another attempt at mobilizing the reader was also made by the avant-garde writers of the hassāsiyyah jadīdah (New Sensibility) in the 1960s. Here, the authors were eager to refrain from acting as authorities or despots who, like Nasser, would use beautiful language and tell readers what it meant. In order to become conscious participants, readers had to find the meaning themselves. ${ }^{11}$ More recently, the young Egyptian writer 'Ahmad AL-'ĀYDĪ used computer language as a fictional device in his novel An takūn 'Abbās al-'Abd (Being Abbas al-Abd, 2003), in order to shake the readers and stimulate their intervention (EL-ARISS 2010).

However, the activation of the reader remains a fictional device in these works. The autofictional blog, in contrast, actively involves the reader, both in the interpretation and the composition of the text. Besides, as it is published online, it allows bloggers to challenge the "holiness" of the literary language that they contest.

\section{The autofictional blog: an interactive 'adab ('adab tafáculì)}

To some extent, blog authors establish their authority over the text the way traditional authors do. Authorship is identified with a real name or a pseudonym, which appears at the end of each entry and on the blog's profile page. Individual ownership is often also established through the customization of various elements of the blog's appearance, through the use of colors, fonts, headers, and personal icons. Blog authors are also able to exercise direct control over access to their territory by others. The majority of interactions takes place on the personal territory of one individual and are initiated, centered around, and regulated by that fact. Bloggers have the ability to restrict readership of their entries; to regulate the posting of comments, either by screening submissions prior to their display or by deleting unwanted comments subsequent to their appearance (MASSERAT 2008). The blogger is the only 'manager of the site' who decides what content can be displayed.

However, the most innovative aspect of Internet diaries and weblogs is that they not only make intimate writings potentially accessible to a multitude of readers, but also grant the reader the opportunity to respond directly to the text. The narrative created through the blog is essentially interactive and, as such, turns the literary text into a collaborative effort (SERFATY 2004: 465). Through its continuous updating over the time, the weblog becomes a text that is constantly transformed through the input of both readers and writers (HIMMER 2004).

In the following, some of the literary strategies applied by Egyptian bloggers to activate their readers shall be discussed. As I will show in the next paragraph, one of the tasks conferred upon the reader is to discover the blurred identity that hides behind the narrated events.

11 For the main traits of this "artistic sensibility" see GUTH 2011 and KENDALL 2006. 


\section{The Blurred Identity of the Author/Main Character}

In an autofictional blog, the narration is typically done in the first person and deals mainly with the main characters' inner lives. The author is driven by a 'quest for truth' (CUSSET 2012) that consists in speaking out, in revealing his/her innermost emotions and feelings. These are considered the essential traits of the blogger's 'true' subjectivity. Autofictional bloggers often write about feelings of alienation, love, fear, desire for freedom. In so doing, they are eager to address 'hot' issues in society, such as sexual harassment, police brutality, homosexuality, or religion, by describing how these issues affect their emotions and bodies.

The representation of consciousness is an element that distinguishes literature from non-literary genres, as argued by Käte HAMBURGER in the book The Logic of Literature (1973: 13). In fact, the scholar Kathleen FITZPATRICK agrees that the literary quality of some blogs consists in "producing a form of subjectivity so pervasive and so apparently natural in a way that transforms blog writing into literature" (2007: 174).

However, in a work of fiction the 'I' of the narrator usually corresponds to an imagined character. In the case of autobiography, it corresponds to the author of the narrative. Autofiction, instead, "has logic of its own, and uses autobiographical experience consciously, explicitly and sometimes deceptively" (ALBERCA 1996: 11). In a blog the 'I' is usually thought to correspond to a character that exists in real life, a character, however, who also interacts with the readers in the comment section, and yet fictionalizes his or her identity in several ways. In the following I will show some of the narrative strategies used by the bloggers that contribute to the blurring of the identity of the author/main character.

\section{Pseudonyms}

One way of fictionalizing one's identity in a blog is to adopt a pseudonym. In Egypt, this was very common, especially in 2005 when the blogging community was still emerging. For many of the bloggers I interviewed, using a nickname was a way of playing with the medium, of trying out a new personality while accessing a different social setting, and not really a means of maintaining personal security, as is often believed.

The playful attitude is evidenced by the fact that most of the nicknames match the idea expressed in the title of the respective blogs. Thus, Gādah 'Abd al-'Āl, the title of whose blog claims 'Āyza 'atgawwiz (Eg. Ar., I Want to Get Married), accordingly signs her posts as "Brāyd" (Bride). Similarly, Riḥāb Bassām introduces herself as "Haddūtah": as the blog is entitled Hawādìt (Stories/Tales), she herself becomes one of these stories-probably even the main story, as the blog is mainly about her personal life. Pseudonyms are often chosen to actualize some of the psychological traits the writer cannot express anywhere else, and may thus express considerable meaning. Adopting a pseudonym may therefore signal that one is entering a distinct universe in which different rules apply and where one's personality may develop to the full (SERFATY 2004: 93). For example, 'Ahmad NĀĞİ has chosen the devil as his online counterpart, as evidenced by his pseudonym "Eblis" 12 (Devil). He clarifies that the choice of this name is meant to highlight his difference from and

12 Transcription of the Arabic word ibliss as used by the blogger himself. 
opposition to his social community. Indeed, according to the Qur'ān, 'Iblīs was the only angel of God to refuse to bow to Adam. ${ }^{13}$ Interestingly, readers often use pseudonyms as well. Thus, bloggers create themselves as central characters in a fictional theater, populated by a large supporting cast of minor characters and readers (SORAPURE 2003: 13).

According to GENETTE, "the use of pseudonyms unites a taste for masks and mirrors, for indirect exhibitionism, and for controlled histrionics with delight in invention, in borrowing, in verbal transformation, in onomastic fetishism" (1997: 54). In his famous study Voyeur Nation, media scholar C. CALVERT argues that, on the Internet or on TV, the corollary of exhibitionism is voyeurism, which he defines as "the consumption of revealing images of and information about others' apparently revealed and unguarded lives, often simply for purposes of entertainment" (2000: 2). In fact, we can see that when the entries are signed with a pseudonym, readers tend to read more actively to discover who is the person hiding behind the false name and then eventually tell it to the others. In order to do so, they might navigate the blog looking for further markers of the author's identity or do some investigating in real life. This is evidenced by the words written by the blogger Nirmīn Nizār:

I opened this blog as a space for chatting without restrictions or fear. I wanted to hide behind a different name; although I knew that many people who know me in real life could easily guess it was me. But my dear friend decided to remove the curtain and reveal my identity to the world. This is not a farewell, not an excuse for leaving; it's just another nonsense talk. ${ }^{14}$

\section{Self-Conscious Narrators}

Another device often used to blur the line between the author and the main character in the narrative is the author's use of him- or herself as a self-conscious/metafictional narrator. Thus, while telling an intimate, confessional account, the authorial voice intrudes into the narrative and questions its authenticity, breaking the verisimilitude of the work. For example, Mahmūd Hasan, author of the blog Șahābìt (Scribbles), inserts a disclaimer for the readers at the beginning or end of several posts:

13 'Who created you, We gave you form and then We told the angels: 'Bow Down before Adam.' They bowed, all except Satan, who was not among those who bowed. He said: 'What prevented you from bowing down when I commanded you?' He said: 'I am better than he: You created me of fire, but him You created out of clay." Qur'än, The Battlements, 7, 11-18, transl. by Tarif Khalidi, Penguin, London, 2008, p. 118. This is also a common phenomenon in Sufism, where Iblīs often becomes a figure of identification for the Sufi (as against the 'orthodox' tradition), cf. art. "Iblīs" in Encyclopedia of Islam, Second Edition.

14 The quotation is taken from the book retrieved from her blog, Iskandariyyah / Bayrūt (Alexandria Beirut), Dār al-Šurūq, Cairo, 2008, p. 64. My translation. 


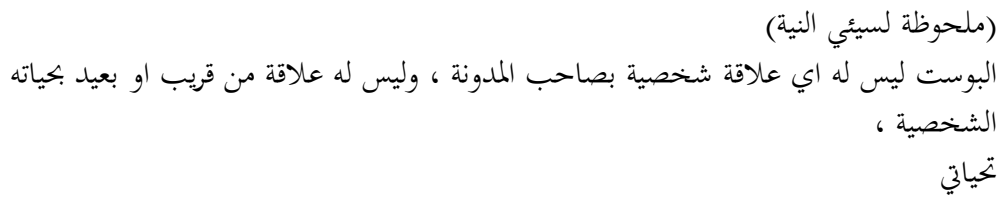

(Note for those with bad intentions)

There is no personal relationship between this post and the author of this blog, nor is there a relationship, be it far or close, with his personal life.

My greetings. (Mirsāl, 6 December 2008)

This technique can often be found in autofictional novels. E. H. JONES believes it may have the opposite effect of enhancing the reader's belief (2009: 180). It may also, however, increase the reader's confusion regarding the 'truthfulness' of the blog. Some readers do indeed inquire about the factual nature of the account by asking the writers directly, as in the following:

$$
\begin{aligned}
& \text { • انت متأكد ان ديه قصه انت مألفها ـ مش عارف ليه مش مصدق }
\end{aligned}
$$

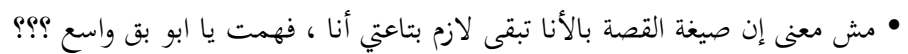

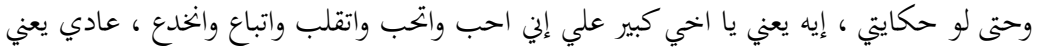

KIMOOZ: Are you sure this is a fictional story? I don't know why, I can't believe it.

MAHMŪD: Why does every story written in the first person have to be autobiographical, $\mathrm{O}$ wide-mouthed one? And even if it is about me, what is the problem in that I love, I am loved; I am tossed around, sold out and cheated?

('As'ilah, 6 June 2008)

Other readers enjoy it as a fictional story and point out that the story addresses their feelings and fosters identification. Resorting to a self-conscious narrator might be a way of protecting one's social respectability while revealing aspects of one's self. But more significantly, it might signal that by presenting it as fiction, by temporarily removing themselves from the story, the authors aim to generalize, objectivize their feelings: their story becomes a story with which any young Egyptian may identify, and this is also one of the tasks generally attributed to literature and 'adab.

\section{Hoaxes (Ǐstiḡälät)}

Bloggers also tickle the readers in a game that they call ištigālah, an expression in Egyptian vernacular that could be translated as 'hoax'. It consists of deliberately fabricating fictional stories and presenting them as truth by using an intimate, confessional tone of narration, with a call for readers' support. ${ }^{15}$

15 Jill Walker illustrates many cases of "blog hoaxes" in her book Blogging. See the chapter "Fictions or Hoaxes?", 2008: 121-126. 
An example of this 'game' can be found in a blog post written by Nāğì, Li-kulli 'awwal bidāyah, li-kulli 'āhir nihāyah (In Every First There Is a Beginning, in Every Last There Is an End; 6 August 2005). On the day this blog is written the narrator announces to his audience that on waking up one morning he realized that he had lost his sight. Dictating to his sister, he announces the news to his readers and asks them whether they could advise him where to get a keyboard with Braille fonts.

Indeed, several readers seem deceived by the medium and assume that what Năği writes is true. ${ }^{16}$ They ask how this could have happened and wish him a quick recovery. Others seem to understand the game and participate in it according to its rules:

$$
\text { ماشوفتش الراجل بتاع كفكا اللي صحى لقى نفسه صرصار؟ على الأقل أنت أهلك لسه حواليك ، }
$$

SPRING: Look at the Kafka man, he woke up and found himself a beetle! At least you still have your family; the other one was left to get rotten!

(24 December 2005)

After several comments the blogger reveals that this post is an "unrestrained excess of imagination, an extravagant fantasy" (šațh haya $\bar{a} l)$. In response, a reader writes:

$$
\text { طلحبث ابقى سيب تنويه يا أخي انه خيال .. فرضاً دخل واحد زيلي عنده عطب في جهاز التفريق بين }
$$

GUEVARA: Put a note saying that this is fiction, do you think we have a machine to distinguish fiction from reality?

(24 December 2005)

Another reader writes: "You made me feel stupid, as usual!"17 Thus, in this post the blogger achieves his goal of using the Internet medium to write a literary text that makes the readers uncomfortable. The literary text turns into an interactive game, a joke almost, played by readers and writers.

Once the readers realize that the story is fictional, they understand that it is meant to express feelings of helplessness and vulnerability. By presenting himself as blind, the character expresses his incapacity for seeing and understanding reality. In addition, writing about blindness is also a way of writing about the act of writing itself. "My sister is typing, and I am insisting that she should put some diacritic signs ( ilāmat al-taškīl) [...], I tell her that they give beauty to the text [...] she types and I don't know how many typos she has made". By pretending to be blind and therefore diverting the blame for these mistakes

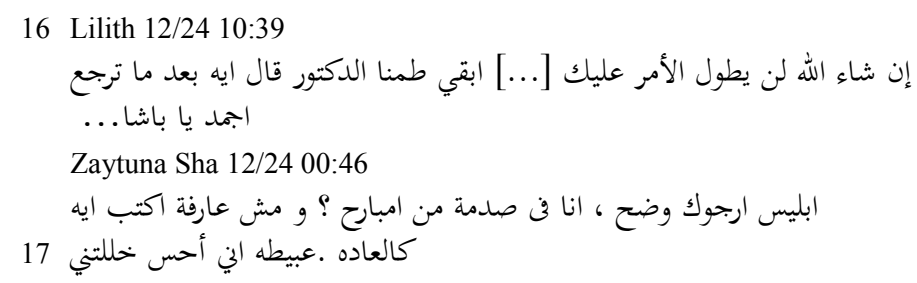


towards his sister, he mocks the strict adherence to language rules on which Arab literati usually insist.

The narrative strategies described so far (pseudonyms, self-conscious narrator, hoaxes) show that the bloggers inject their writing with their personal subjectivity, but they blur their identity in order to involve the readers in an active game of interpretation. In addition, we must notice that the blog changes the way of writing and reading, because of its multimedial nature and its non-linear, open-ended structure. Therefore it demands that the reader choose his/her own way of reading and making sense of the text.

\section{Multimedia Open Texts}

In the autofictional blog, as in other forms of electronic literature, writers combine written texts with elements drawn from other media, such as visuals and audio.

Often writers insert personal pictures into the narrative. They help to assure not only the readers but also the writers of the reality of their existence. It must be kept in mind, though, that these pictures could easily be fabricated. Apart from personal pictures, blog entries may also include drawings, pictures of contemporary art, and other sorts of images. Pictures contribute to the meaning of the text, or help set the mood for the story.

For example, the blogger Munà SAYF began to experiment with drawings when she started blogging, in order to make her blog more personal and original. Thus, many of her blog posts combine text with very simple drawings.

In several other entries Munà depicts herself as a small child, both visually and verbally. For her, taking refuge in an imaginary childhood is a means of ignoring, or forgetting, a reality marked by the cruelty of the political regime. In fact, as she writes in the post "Ḧāyfa" (Scared; 4 May 2007), "I am scared, and the more fear clinches into me, the more childish I become". Munà's self-depiction of childish instinct is neatly juxtaposed with the description of a more mature, rebellious, passionate woman. In these entries she displays her hair as long, curly, and loose. Here the hair emphasizes the feminine and rebellious side of her personality, the longing for freedom instead of imprisonment and unfolding femininity.

Similarly, the outline of the blog The Red Sofa reveals Bilāl's passion for visual arts. Both in the header of the blog and in the right-hand margin, Bilāl uploads pictures of Jennifer Garant's paintings showing whimsical chefs riding bikes and mopeds and carrying food and wine. The profile picture also depicts a chubby chef clumsily serving two bottles of wine. By choosing this picture, the blogger is highlighting the corpulence of his body, which is also depicted in his writing. Additionally, he informs his audience of the possibility that his blog may contain some elements considered harām (forbidden by Islamic law) by more conservative readers. To more liberal readers, however, the illustrations can be seen as an invitation to fill a glass, sit on his red sofa, and enjoy his stories.

Readers may also have a say in the visual aspect of the blog. In The Red Sofa, some commentators complain about the color of the font chosen by Bilāl and advise him to choose a different color:

$$
\text { والله يا أستاز كنبة أسلوبك فن الكتابة زريف وغريب بس ياريت لو مافيهاش رزالة تكبر الفونت وتخلى }
$$


Really, Prof. Sofa, your writing style is nice [zariff] and strange, but if it is not a hassle, could you increase the font size and make the background [albāg grāwnd] lighter? (3 July 2007).

Authors also combine texts with audio or video elements. Entries on the 'Arabiyyat al-fül blog, for example, always include a song. The author explains that the song is usually one that he was listening to while writing the associated post. It is meant to reproduce the writer's mood during the post's composition, and to put the readers in the same atmosphere. Often authors include music videos from YouTube.

The combination of these media transforms reading into a multi-sensorial experience. It also requires the reader to make an effort to interpret the text: he or she has to make sense of different semiotic resources. The meaning of the text stems or emerges from the combination of audio, video, and visual elements (SERFATY 2004: 27).

Furthermore, this hybridization of the text by mixing written words with other media prevents the construction of a unified linear account while creating new meaning and opening up new spaces for interpretation (SERFATY 2004: 29). This disruption of the linearity is also obtained via the embedding of links into the narrative, which I will analyze in the next paragraph.

\section{Links}

While printed literary texts are usually enclosed between the covers of a book, online narratives are structured as a database, described by POSTER as "an engine for producing retrievable identities" (1995: 89). In this way, the database produces identities that can be dispersed across numerous sites, but pulled together through whatever particular filter or search function is in operation at the time.

Even though the simultaneous appearance of the bits of information on a website produces a certain unity, the narrative is expanded through links. For example, in the blogroll, we find a list of links to blogs or websites the author reads frequently. This list of links is an important part of the blogger's self-representation because it conveys a picture of the blogger's cultural, aesthetic, and social affinities, and thus his or her identity. Links also add to the reader's sense of the blog's "authenticity" because the narrative is anchored in real places and features people whom members of the audience may also recognize, making them feel part of the narrative (MCNEILL 2003: 33). Links are also inserted into the main text and expand the narration outside the blog space. A common practice that I found in Egyptian blogs is to insert a link to another blogger's online diary whenever he or she is mentioned in the narration. In this way the author gives the reader the chance to gain a greater understanding of the characters through their blogs.

This space distribution opens the way for a random exploration instead of one specific way of reading; thus readers have to find their way through the different paths to which hyperlinks lead. HIMMER (2004) argues that the term 'ergodic literature,' as coined and defined by E. AARSETH in his famous book Cybertexts: Perspectives on Ergodic Literature, may well be applied to blogs. Ergodic literature-AARSETH derives the term from the Greek words for 'work' and 'path' (érgon and hódos, respectively) — is a type of literature 
that requires significant effort on the part of the reader in the construction of the text. ${ }^{18}$ In other words, the reader can open and begin reading the weblog at any point along the process of its production from the oldest, earliest post to the most current. A reader can use an internal search mechanism (common on many weblogs) to seek particular topics or terms or browse by category, month, or day, all of which offer myriad paths through the narrative "space" of the weblog, or to other weblogs, articles, or general websites (HIMMER 2004). In this sense, the reader's pleasure is equivalent to that of exploring a labyrinth, a game, or an imaginary world in which he can get lost, discover secret paths, and play around.

\section{Ongoing Narrations}

The spatial distribution of the narrative runs parallel to its temporal distribution. A defining quality of a blog is its dynamic updating within a dated entry format.

FITZPATRICK argues that like any work of literature the blog has a plot. However, this plot is not planned beforehand but it is constituted by the accumulation of the posts published regularly on the blog (2007: 168). Each post makes sense in itself, but read together, the multiple entries compose a larger story. Blogs are not merely a way of writing the self, they are "a continuous way of writing oneself" (MORTENSEN \&WALKER 2002: 258; emphasis added), they are "published bit by bit; they are always in progress, always becoming" (2002: 267). Thus also the author/main character's identity is never fixed; rather, it is a dynamic identity, which changes over time.

This refusal of closure, this interruption, deferral, and waiting, produces in the readers the desire to return to the blog site and therefore brings it close to earlier narrative forms such as the epistolary novel, but also the soap opera (FITZPATRICK 2007: 174). In fact, the novel reader's or soap opera watcher's desire to reach the end may be compared to the blog reader's waiting for the next blog entry. Sometimes the blogger also inserts cliffhangers to make the narration more compelling. ${ }^{19}$ However, while novelistic forms and the soap opera do have ends, most diaries don't. Some bloggers in my research sample have stopped blogging, but without giving a definite end to the narrative. They have simply stopped writing. They might come back at any time, and the simple fact that the blog is still online gives the reader hope that they will.

In addition, in the blog the plot is not driven exclusively by the author. Readers can also contribute to the plot's development.

In many cases, the readers go to the comment section to congratulate the bloggers on their writing style or to describe the feelings provoked by their reading. Often readers add personal anecdotes to the story.

Readers may also provide a sudden twist to the narration, by changing the direction of the plot. This is evidenced in The Red Sofa, in which the blogger tells the story of his daily life on the sofa that he has inherited from his mother, who died shortly before. One day one

18 AARSETH positions in this category both print and digital literature, thus including not only hypertexts but also classic texts as the I Ching and Raymond QuENEAU's One Hundred Thousand Billion Poems.

19 An example of that can be found in the blog al-Kanabah al-Hamra by Bilāl HuSNī. He concludes one of his posts (6 January 2007), writing: "تابعوني الكنبه الحمرا جنب المرتبه الاورنج / الولاد بتنام على ضهرهم Follow me, the red sofa beside the orange mattress / the lazy guys (lit. who sleep in supine position)”. 
reader suggests auctioning off the sofa. This leads to an unexpected development of the narrative. As a consequence, the blogger decides to write an imagined version of the story of the sofa, in order to attract more readers to the auction. In this account, the sofa is turned almost into a human being that could be seen as the author's fictional alter ego. This example shows that a reader may provide creative ideas to the writers. The writers, in turn, may incorporate and develop them in the literary text.

\section{Mixed Arabic as a Literary Language}

My last point concerns the stylistic choices made by bloggers. Since blogs are interactive, they are seen not only as a platform for writing but also as a means to communicate with the readers. In addition, blogs are self-published; therefore they do not undergo the scrutiny of editors or publishers who, as mentioned above, tend to expect works of literature to be written in a high variety of language, i.e., Modern Standard Arabic (MSA). This allows an unrestrained freedom to make stylistic choices.

Autofictional bloggers have a distinct voice that elevates the style of the blog to the level of literariness. Their language is emotional and is also embellished with metaphor and alliteration. Dialogue is also rendered as direct speech to attribute more literariness to the text. However, bloggers forge this language by mixing MSA, the formal variety of Arabic, together with vernacular, youth slang, and English. Mixed together, these different language varieties create an original style that raises the language of blogging above the ordinary and makes it literary. We can also notice a playful spelling, with excessive lengthening of vowels to imitate the accentuated pronunciation of the words. Short sentences are often combined with very long passages, but also ellipses are heavily used; taken together, these may indicate the flow of thoughts, indeterminacy, pauses, or hesitation characteristic of face-to-face conversation.

It is also rather common to find mistakes and misspelling of works that are left intact by the bloggers to give more immediacy and spontaneity to the work.

In modern Arabic literature, the use of this language in literary works is an innovation brought about by blogging. ${ }^{20}$ Readers often point out in the comment section that they enjoy this style as it speaks directly to their heart. This language expresses the creative needs of a young, globalized, tech-savvy generation. On the other hand, one may find that

20 Research in the history of Arabic has shown that mixed varieties that combine standard and colloquial features with others of a third type, neither standard nor colloquial, have been in use since early times (called "Middle Arabic"); here, authors would write in MA because they found it appropriate, usually in less formal genres or sometimes simply because they were not fluent in Classical Arabic. However, since the 19th century, during the period of cultural reform that is known by the term Nahdah (Renaissance), Arab literati have stressed the need to preserve the beauty and purity of fush $h \bar{a}$ by using a modern version of it, linked to the historical tradition and intellectual splendor of Ancient times, which could be used at the same time as a Pan-Arab national language and to address the entire Arab nation. See the entry "Middle Arabic" (Jérôme Lentin) in the Encyclopedia of Arabic Language and Linguistics, <http://referenceworks.brillonline.com/entries/ encyclopedia-of-arabic-language-and-linguistics/ middle-arabic-COM_vol3_0213?s.num=0\&s.q=middle+arabic $>$, accessed 11 October 2013, 235. - It is noteworthy that the blogs published in print underwent very little stylistic editing, leaving the immediacy and spontaneity of this writing untouched. 
sometimes readers contest it and reproach the writers for the shortcomings of their writing and their lack of mastery of literary language. In fact, they do not hesitate to point out linguistic and typographical errors within the text, as in these cases:

$$
\text { نفسي بس لو تنصب المفعول واسم إن وخبر كان، لو ده حصل هتبقى كاتب عظيم }
$$

I would just like you to put the manșūb endings to direct objects, the subject of 'inna and the predicate of kāna; if that happened, you would be a great writer.

(24 December 2005)

This is another example of how the readers challenge the authority of the writer. The writer is not seen as the master of the text whose form cannot be questioned, but as the author of a text that can be constantly changed thanks to the collaboration of readers and writer. Apart from that, it shows that readers take over the job of editors and proofreaders, as they cooperate with the writer in the attempt to ameliorate the literary text. In addition, the informal tone of these comments suggests that in the blogosphere the author and the reader are equals.

\section{Conclusions}

In this paper I have focused on the unique features presented by the autofictional blog, resulting from the adoption of the Internet medium. In the analysis of these features, I have focused on the reader's involvement as a way to understand the specific literary quality of the blog. I have argued that by carrying a useful message that the readers have to interpret by themselves and that they can contribute to shaping, the autofictional blog acquires features of traditional 'adab. First, readers are called to discover the identity behind the screen, making sense of pseudonyms, self-conscious narration, and hoaxes and gathering fragments of the author's real identity scattered through the blog. Second, readers have to make their own way through the labyrinth of the open, multimedia text, by reading text together with pictures, selecting links and browsing different pages, playing music and videos. Third, readers are invited to return to the narration, as the blog is continuously updated; new pieces are added to the main story over time. Readers can continuously interact with and contribute to the plot of the blog by adding their own stories in the comment section. They can also have a say in the visual layout of the blog and the stylistic features of the narrative.

In short, it can be seen that the blog presents some elements of literariness (in the western sense), such as fictionality, personal subjectivity, plot, and literary language, but that it also carries on features of traditional 'adab (as developed from classical 'adab since the 19th century nahdah). Moreover, I have also shown how the blog complicates the understanding of both, 'adab and literature (in the western sense) alike, in several ways: the literary is mixed with the non-literary, the plot is fragmented and always in progress, Modern Standard Arabic is mixed with language varieties that are usually not considered "literary" in the Arabic domain. 
Autofictional authors activate the readers by disclosing their own life story, expressing intimate feelings and emotions. They invite readers to change the reality of the text by pushing a button, by clicking and navigating from one link to another, and by posting their own stories in the comment section. It is from this interaction that new communities of authors and readers emerge. Within these communities, new values, stories, and subjectivities are being played out, discussed, and validated.

\section{References}

\section{Primary Sources}

'ABD AL-'ĀL, Ġādah [alias BRĀYd]. 'Āyzah 'atgawwiz [I Want to Get Married]. <http://wanna-b-abride.blogspot.com/>.

'ALĀ BĀB ALLAH (pseud.) $\rightarrow$ HalīM, Jimmy.

al-'ĀYdī, 'Aḥmad. 2003. 'An takūn 'Abbās al-'Abd (Being Abbas el-Abd, 2003, Eng. Transl. 2006), Cairo, Dar Mirīt.

BASSĀM, Rihām [alias ḤADDŪTAH]. Hawādīt [Stories]. <http://hadouta.blogspot.com/>.

BRĀYD (pseud.) $\rightarrow$ 'ABD AL-'ĀL, Ġādah.

HADDŪTAH (pseud.) $\rightarrow$ BASSĀM, Rihām.

ḤALĪM, Jimmy [alias 'AlĀ BĀB ALLĀH]. 'Arabiyyat fül [The Fava Beans Cart]. <http://al-karma. blogspot.com/>.

ḤASSAN, Mạ̣mūd. Šahāāiṭ [Scribbles]. <http://shkhabit.blogspot.com/>.

Husnī, Bilāl. Al-Kanabah al-Hamrā [The Red Sofa]. <http://knbahmra.blogspot.com/>.

'IBLĪs (pseud.) $\rightarrow$ NAĞĪ, 'Ahmad.

MONASOSH (pseud.) $\rightarrow$ SAYF, Mūnà.

NAĞĪ, 'Aḥmad [alias 'IBLĪs]. Wassi' hayālak [Enlarge Your Imagination]. < http://ahmednaje.net/>.

NiZ̄̄e, Nirmīn. 2008. 'Iskandariyyah/Bayrūt [Alexandria/Beirut]. Cairo: Dār al-Šurūq.

SAYF, Mūnà [alias MonASOSH]. Tanātīf Mā'at. <http://ma3t.blogspot.com/>.

SULAYMĀN, 'Abīr. Yawmiyyāt 'ānis. <http://yawmiyat3aness.blogspot.com/>.

'UBAYD, 'Isā. 1964 [1921]. Iḥsān Hānim. Cairo: al-Dār al-Qawmiyyah li-l-Ṭabā'ah wa'l-Našr.

\section{Works Cited}

Aarseth, Espen. 1997. Cybertext. Perspectives on Ergodic Literature. Baltimore: John Hopkins University Press.

ABdel-Messin, Marie Thérèse. 2009. "Hyper Texts: Avant-gardism in Contemporary Egyptian Narratives". Neohelicon, 36/2: 515-523.

AlBERCA, Manuel. 1996. "El pacto ambiguo: ¿Es literario el género autobiográfico?” Boletín de la Unidad de Estudios Biográficos, 1: 9-18.

ARISS, Tarek El- $\rightarrow$ EL-ARISS, Tarek.

BRADFORD, R. (ed.). 2009. Life Writing. Basingstoke UK: Palgrave Macmillan.

CAlvert, Clay. 2000. Voyeur Nation: Media, Privacy and Peering in Modern Culture. Boulder, Colo: Westview Press. 
Cusset, Catherine. 2012. "The Limits of Autofiction". Paper presented at Conference on Autofiction, April 19-21, 2012, New York University. Retrieved September 4, 2013, from <http://www. catherinecusset.co.uk/wp-content/uploads/2013/02/THE-LIMITS-OF-AUTOFICTION.pdf $>$.

EDZARD, Lutz / Guth, Stephan (eds.). 2010. Verbal Festivity. Wiesbaden: Harrassowitz.

EL-ARISS, Tarek. 2010. "Hacking the Modern: Arabic Writing in the Virtual Age". Comparative Literature Studies, 47/4: 533-48.

El-SADDA, Hoda. 2010. "Arab Women Bloggers: The Emergence of Literary Counter publics". Middle East Journal of Culture and Communication, 3: 312-332.

- . 2012. Gender, Nation and the Arabic Novel. Egypt, 1892-2008. New York: Syracuse UP.

FARIS, D. 2013. Dissent and Revolution in a Digital Age. London: I.B. Tauris.

FitZPATRICK, Kathleen. 2007. "The Pleasure of the Blog: The Early Novel, the Serial and the Narrative”. In T. BuRG, J. SHMIDT (eds.), Blogtalks Reloaded, Wien: Books on Demand. Retrieved March 3, 2012, from <http://machines.pomona.edu/dossier/files/2009/10/fitzpatrick-blogtalk.pdf>.

GeneTte, Gérard. 1997. Paratexts: Thresholds of Interpretation. Cambridge: CUP.

Guth, Stephan. 2010. "Politeness, Höflichkeit, 'adab: A Comparative Conceptual-Cultural Perspective". In EDZARD \& GUTH (eds.) 2010: 1-29.

— . 2011. "Literary currents in Egypt since the beginning/mid-1960s". In: From New Values to New Aesthetics: Turning points in modern Arabic literature, ed. S. Guth \& G. Ramsay, vol. I: From Modernism to the 1980s, Wiesbaden: Harrassowitz, 2011: 85-112.

— . 2013. "Novel, Modern Arabic". In Encyclopedia of Islam, $3^{\text {rd }}$ edition (online), ed. by Gudrun KRÄMER [et al.], Brill Online, 2014. Retrieved July 10, 2014 from: <http://referenceworks. brillonline.com/entries/encyclopaedia-of-islam-3/novel-arabic-COM_27115>.

HAMBURGER, Käte. 1973. The Logic of Literature. Bloomington: Indiana UP.

Himmer, Steve. 2004. "The Labyrinth Unbound: Weblogs as Literature". In L. GURAK, S. ANTONIJEVIC, L. Johnson, C. RAtLiff, and J. Reyman (eds.), Into the Blogosphere, Minnesota: University of Minnesota. Retrieved October 7, 2011, from <http://blog.lib.umn.edu/ blogosphere>.

JACQUEMOND, Richard. 2008. Conscience of the Nation: Writers, State and Society in Modern Egypt. Cairo: AUC Press. [Original French version: Entre scribes et écrivains: Le champ littéraire dans l'Égypte contemporaine, Arles, 2003].

JONES, Elizabeth H. 2009. “Autofiction: A Brief History of a Neologism”. In BRADFORD (ed.) 2009: 174-184.

LeJEunE, Philippe. 2000. Cher Écran. Paris: Seuil.

KENDALL, Elisabeth. 2006. Journalism, Literature and the Avant-Garde: Intersection in Egypt, London/New York, Routledge.

KLEMM, Verena. 2000. "Different Notions of Commitment (iltizām) and Committed Literature (aladab al-multazim) in the Literary Circles of the Mashriq". Arabic and Middle Eastern Literatures, 3.1: 51-62.

Masserat, Amir-Ebrahimi. 2008. "Transgression in Narration: The Lives of Iranian Women in Cyberspace". Journal of Middle East Women's Studies, 4/3 (Fall). Retrieved November 29, 2011, from <http://muse.jhu.edu/journals/journal_of_ middle_ east_womens_studies/v004/4.3.amirebrahimi.html>.

NĀĞ̄̃, A. 2010. Min al-Post ilā al-Tweet (From posts to tweet). Cairo: ANHR press (in Arabic). 
MCNeILL, Laurie. 2003. "Teaching an Old Genre New Tricks: The Diary on the Internet”. Biography, 26/1: 24-47. Retrieved October 10, 2013, from <https://muse.jhu.edu/journals/biography/v026/ 26.1meneill.html>.

Mortensen \&WALKer. 2002. "Blogging Thoughts: Personal publication as an online research tool". In A. MORRISON (ed); Researching ICTs in Context, pp. 249-79. InterMedia Report, 3/2002, Oslo. Retrieved June 13, 2013, from: <http://www.intermedia.uio.no/konferanser/skikt-02/docs/ Researching_ICTs_in_context-Ch11-Mortensen-Walker.pdf $>$.

Neuwirth, Angelika / Pflitsch, Andreas / Winckler, Barbara (eds.). 2010. Arabic Literature: Postmodern Perspectives. London \& Beirut.

PePe, Teresa. 2011. "From the Blogosphere to the Bookshop: Publishing Literary Blogs in Egypt". Oriente Moderno, Nuova Serie, 91/1 (= special issue Between Everyday Life and Political Revolution: The Social Web in the Middle East): 75-90.

—. 2012. "Autofiction on Screen: Self-representation of an Egyptian 'Spinster' in a Literary Blog". Journal of New Media Studies in MENA, 1: 1-10.

Pflitsch, Andreas. 2010. "The End of Illusions. On Arab Postmodernism”. In NeuwiRTh / Pflitsch / WiNCKLER (eds.) 2010: 25-40.

Poster, Mark. 1995. The Second Media Age. Cambridge: Polity.

Queneau, Raymond (1961). Cent mille milliards de poems. Paris: Gallimard.

RADSCH, Courtney. 2008. "Core to the Commonplace: the evolution of Egypt's blogosphere”. Arab Media and Society, September 2008: 1-14.

SADDA, Hoda el- $\rightarrow$ EL-SADDA, Hoda.

SELIM, Samah. 2004. The Novel and the Rural Imaginary in Egypt, 1880-1985. New York, London, Routledge.

SERfATY, Viviane. 2004. The Mirror and the Veil: An Overview of American Online Diaries and Blogs. Amsterdam \& New York, Rodopi.

SORAPURE, Madeleine. 2003. "Screening Moments, Scrolling Lives: Diary Writing on the Web". Biography, 26/1: 1-23.

WALKER, Jill. 2005. "Blog". In D. Herman (ed.), The Routledge Encyclopedia of Narrative Theory, New York: Routledge: 45. Retrieved 3 December, 2011, from: <http://huminf.uib.no/ jill/ archives/blog_theorising/final_version_of_weblog_definition.html $>$.

- . 2008. Blogging. Cambridge: Polity.

(C) Teresa Pepe, University of Oslo, Norway

$\checkmark$ teresa.pepe@ikos.uio.no 